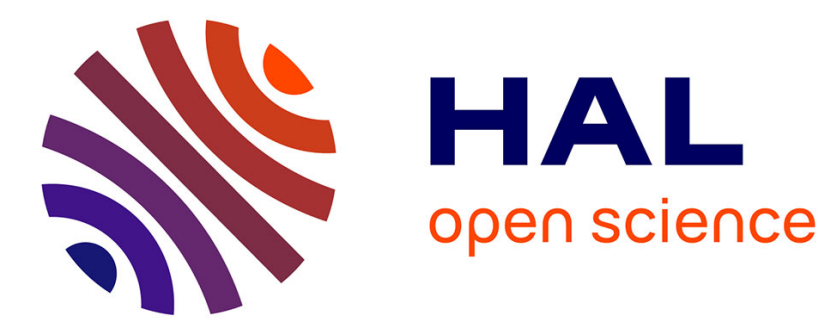

\title{
The mystery of the dying language
}

James Leach

\section{- To cite this version:}

James Leach. The mystery of the dying language. Journal of Ethnographic Theory - HAU, 2020, 10

(2), pp.660-663. 10.1086/709967 . halshs-03040131

\section{HAL Id: halshs-03040131 \\ https://shs.hal.science/halshs-03040131}

Submitted on 6 Jan 2022

HAL is a multi-disciplinary open access archive for the deposit and dissemination of scientific research documents, whether they are published or not. The documents may come from teaching and research institutions in France or abroad, or from public or private research centers.
L'archive ouverte pluridisciplinaire HAL, est destinée au dépôt et à la diffusion de documents scientifiques de niveau recherche, publiés ou non, émanant des établissements d'enseignement et de recherche français ou étrangers, des laboratoires publics ou privés. 
BOOK SYMPOSIUM

\title{
The mystery of the dying language
}

\author{
James Leach, Aix-Marseille Université and University of Western Australia
}

Comment on Kulick, Don. 2019. A death in the rainforest: How a language and a way of life came to an end in Papua New Guinea. Chapel Hill: Algonquin Books of Chapel Hill.

In recent public talks, Don Kulick has joked that he has been unlucky with book titles. Remembering his first book, Language shift and cultural reproduction: socialization, self and syncretism in a Papua New Guinean village, and then several subsequent ones with more and more outrageous (proposed) titles which he was not allowed to use, Kulick is as engaging, self-deprecating, and humorous in person as he is in his prose. As to the title of that first book, he laughs that it could not have been much more off-putting if he had tried.

But here, in his latest book, we have a different approach. One that deliberately targets a less academic audience, and one that is reflected in the title, $A$ death in the rainforest. In fact, one wonders if the publishers rather hoped it might be mistaken for a murder mystery on airport bookstands. The book does take that genre of writing as a foil in some ways. It is structured around a mystery, and many little mysteries appear and are solved as the text progresses, building towards the revelation of what, or who, is responsible for the death of a language.

This being the case, as P.G. Wodehouse once put it, "those who read thrillers are an impatient race. They chafe at scenic rhapsodies and want to get on to the rough stuff. When, they ask, did the dirty work start? Who were mixed up in it? Was there blood, and, if so, how much? And - most particularly - where was everybody and what was everybody doing at whatever time it was? The chronicler who wishes to grip must supply this information at the earliest possible moment" (1937: 1).
Kulick does not disappoint. From the very opening pages, we get fantastic characterization, plenty of intrigue, and many plot threads. One is the notion of loss (how and why does a language die out?), another of risk and danger (the rainforest in Papua New Guinea is a tough place to be), another the terrible food, and the incessant demands of his neighbors. We learn about the characters ("Big Bel," the "wannabe corrupt politician" [p. 1]); various possible language teachers who are either recalcitrant, or grumpy, or who mumble; the local lotharios in comic mistaken identity situations, and so on. Yet from the outset Kulick also conveys a sense of common feeling that complements the valuation of difference that motivates his persistent and dedicated work there.

Rather against Wodehouse's advice, though, Kulick does spend quite some time on "scenic rhapsodies," although rhapsody is the wrong term in this instance. A major character in the book is the "rainforest," better thought of, we are told, as "the jungle" (p. 16), but actually characterized as "the foul sago swamp where Gapun lies" (p. 191). These surroundings become a major theme as he details the context of many years of research in a small, hard to reach village near the mouth of the Sepik river in remotest Papua New Guinea. Kulick's character is in a constant battle with this foe, at times a capricious trickster with slippery logs to upend him in muddy bogs everywhere; at times more serious and life threatening. "Death adders" and vicious plants abound, as we are often reminded. And the food is made to sound so repulsive that it, too, is more than 
just unappealing. These things are part of the character of the place. Descriptions of them serve as a constant source of humorous asides, and of running jokes. They help establish as the hero of the story the researcher who braves them in order to be with people that he clearly feels connection to and sympathy with, and to undertake a research task we cannot but see as worthy.

It is part of the plot of this book, then, that the anthropologist is a more or less naïve, and often incompetent, victim of this miserable place. His sense of thrownness is an important part of how Kulick develops his persona in relation to his "hosts." His strategies, privations, and accommodations become one of the threads in the mystery. How does one live in such a place as a pampered white man? And why should anyone accept him there? Not without the kindness of strangers, is the answer. Despite a legitimate suspicion of the trope of self-deprecation in popular anthropological accounts, anyone who has undertaken fieldwork in similar situations will laugh along with Kulick in recognition. But there are questions one might still ask about this use of humor, so often turned on the author himself, but also reliant on the incomprehensible and wildly foreign ways of the people among whom he lives. It carries the danger of constructing the other as a humorous spectacle. And there is a sense, in spite of a strong and committed reflexive awareness, that there is so much that is strange and at times incomprehensible going on around him that we need his presence and his expertise to see through the absurdities of life in such a place, and to understand why people live with so many, often selfinduced, hardships and uncertainties. $\mathrm{He}$ is an intrepid investigator after all.

There is a dissonance between the perceptions of the outsider, the anthropologist, the reader, and the Gapun villagers that Kulick describes, which I wish to dwell on for a moment. As I say, Kulick plays up the physical discomforts of living in a "sago swamp" as a recurring trope. But I wanted, as I read, to consider for a moment whether the villagers themselves actually find it uncomfortable. As much of the narrative that is so important to the book's aims is about their dissatisfaction with their situation, it might appear they also hate the swamp. But that would be misleading. Theirs is a more profound dissatisfaction, as Kulick comes to show, not with the physical hardships that appear so important to the author, but rather with the sense that they are missing out on the immortality and material wealth enjoyed by people in other "countries." As he shows most eloquently, it is this dissatisfaction with the mortal condition of human life compounded by a vastly unequal colonial situation, one which has rendered them powerless in so many ways, that propels their desire for change, their embrace of every crazy scheme which appears to offer it, and thus their virtually unconscious move towards the language of the "modern" world they seek.

Kulick's book is a tour de force, then, of accessible, humorous, and empathetic description, delivered in engaging and inclusive prose, and with a level of insight into both human foibles and human language change, that makes this book almost irresistible. I, along with others I have introduced it to, could not put it down. It is a page turner, appropriately for the murder mystery genre, yet perhaps still unusual and surprising in a popular anthropology book about long-term fieldwork. But in finding it so captivating, I should admit to previous.

In 1991, as I was preparing to leave for fieldwork in Madang Province, Kulick published a letter in Anthropology Today. In it, he related a horrific story of the fatal shooting of a close neighbor in a botched raid on his house in the jungle, and how subsequently, and significantly, he had decided that Papua New Guinea was too dangerous to do fieldwork in. ${ }^{1}$ My supervisors and I discussed the article and its implications, and, not without trepidation, I decided that I would proceed with my plans. As it happened, I was engaged in a wrangle with funders over the cost of equipment that I deemed necessary for the trip, one item of which was a short-wave radio. It was in my kit list in order that I might listen to local "service" broadcasts. The funding body's personnel in charge of overseeing postgraduate research expenses considered it a luxury. I argued it was essential, citing Kulick's article in order to point to the potential dangers of being out of touch with local events. ${ }^{2}$ I got my radio.

I also got into a relationship with a place and a people that has been sustained over twenty-seven years - only seven short of Kulick's own span of involvement with Papua New Guinea. And much like Kulick describes here, this period has had many ups and downs, many moments of high excitement and of deep connection,

1. "I think the time has probably come to start seriously rethinking doing research in PNG" (Kulick 1991: 22).

2. Kulick argued for "grant funding institutions, to accept that researchers going to PNG need things like shortwave radios and outboard motors or whatever, to be able to contact someone in case of emergencies" (1991: 21). 
many of despair and desire to disengage. What brings such highs and lows?

The answer is what Kulick evokes with his close observation, narrative unfolding, and empathy. It is a world that I often characterize as that of human relationships lived at double (or sometimes triple) intensity. If you think relations to your family members are intense at times, imagine people who only live in each other's thoughts. The mediations of the modern world are not only distant, but inappropriate for the density and immediate sociality that is the wave of life, buoying any visitor or resident along through the collective currents of people in mutual, close, deeply connected interdependence.

The intensity of this "unmediated sociality"3 is apparent in Kulick's account. It is apparent in the experiences he recounts of being "already known," assumed to be a returned (deceased) villager (there is no one who is not already known and related). It is there in his gentle complaints about constant requests from villagers for small (and large) items he may be able to give them, requests which are clearly made more for the opportunity for interaction with him than the value of the items given. Indeed, it is also there in the way he reveals that there is a slight edge to these requests. If someone does not cooperate, share, give what they have, then it is a blip in the relationship, a willingness to perturb the thinking of the other in ways that, when all health and well-being rely on others' goodwill and cooperation, may lead to unconscious maleficence, or even conscious sorcery. Life lived in these circumstances is intense.

Kulick also conveys the joy of constant camaraderie, of the implicit acceptance by others of those who arrive or are in the village: they are already related. Schemes and strategies are always at play, disputes and rancor, sickness and death are constantly in the background, too, but they are the schemes and strategies, the thoughts and concerns of people who are also oneself. The acceptance of an unappealing character like "Big Bel" with whom the book opens is not a dimwitted acceptance by the gullible, but the necessary acceptance that this is another person, and that this other person is there to stay. As Kulick illuminates quite brilliantly, in this situation, one in which children are not taught anything but are seen to develop their own understanding over time, different behaviors and characters are not the sub-

3. A phrase used by Giles Lane. See https://gileslane.net /2020/03/04/book-and-bilum/. ject of sanction. People are just like that. We may not like it, but that is who they are! Kulick's book makes it clear that this acceptance is wonderful to feel, even if, as preoccupies him, its consequences can be frustrating, especially when repeatedly ill-informed, self-serving, or destructive initiatives undertaken in the service of bringing change, make peoples' lives in Gapun much less happy or easy.

The core focus of the book is the "death" of the isolate language of Gapun, called Tayap. Kulick's illumination of this death is interesting both for his concise and persuasive summary of why the language is dying out, and also for the subtle way that inexorable loss is abetted by aspects of the context he does so much to establish. But as Kulick makes clear, the question is, a loss for whom? Villagers poignantly bemoan many things about their situation. But what they do not seem to care about is the "loss" of their unique language, or way of life.

Kulick lays the blame for the death of the language on two forces. First, "Like a gigantic, implacable bulldozer, the twentieth century crushed the life out of everything that people in Gapun-and most everywhere else in Papua New Guinea-had ever believed or accomplished" (p. 249). And second, "Throughout the twentieth century, and continuing today, villagers have been exploited, deceived, lied to, humiliated, cheated, and robbed by practically every outside person, entity or organization with whom they have had contact. They haven't just been pawns in this process - they have actively and enthusiastically sought these contacts, and they have wanted to change" (p. 250).

In part, then, the loss of the language is facilitated by the desire for change. It is not a conscious collective decision. Not to speak Tayap amongst themselves, and not to teach it to their children, is not a policy Gapun villagers have agreed upon. Yet in each and every interaction between mother and child that uses the more direct and relevant-seeming lingua franca over the native language, Kulick reveals another tiny moment of loss. His description of parenting, and indeed, of the many uses of language (including obscenity), contribute detail and intimacy to our understanding of Gapun village, and of the increasing atrophy of the tongue there.

Kulick asks the pertinent questions here-and that, again, are part and parcel of the whole mode of reflexive and self-deprecating awareness.

What does it matter if a language dies? And to whom?

What dies? And what, other than rhetorical flourish, does the notion that something as abstract as a way of 
life, or even a language, is something that could "die," say about how we understand these things?

One fascination of this book lies in the way these questions highlight exactly the different concerns of the western scholar, who has a sense of a common humanity, a common heritage for mankind, that is being constantly eroded, and the Gapun villager, who believes that as language acquisition was her own achievement, and no one taught her, it is her own, her own to do with as she pleases.

Kulick's book makes one realize how superbly difficult it is to describe anything properly. One can understand and empathize, yet this is not the same as being able to describe, with nuance, all the facets and intricacies of a social world. The book stimulates this thought because of its clear prose, its startling and yet subtle revelations, and yet the fact that, transparent to the writer himself, there is always something more that one could say, more context and more history, more nuance than can be delivered in reportage prose. Perhaps successful writers of detective novels master the art of creating what you (as the reader) do not know. This book, though, has a different intention for all of its "mystery." It con- veys a huge amount of information about the social world it renders, and nothing is meant to remain a mystery. The hidden and the unsaid are secreted, in the very language and prose itself, into a hither land behind the humor and narrative that causes the reader to plough headlong through the book, and finish it rewarded by vivid images and memories, and also by a sense of human tragedy. But an answer to the "problem" of language loss in Gapun? Well, no. Kulick's last paragraph describes his disengagement, his decision to repeat his previous decision to leave Papua New Guinea for good, and for the same reasons. This disengagement provides a truly sad ending. The question that animates the book: how and why does a language die? is in the end answered yet remains intractable to him. It is because of other people.

\section{References}

Kulick, Don. 1991. "Letters: Law and order in Papua New Guinea." Anthropology Today 7 (5): 21-22.

Wodehouse, P.G. 1937. Lord Emsworth and others. London: Herbert Jenkins.

James LEACH is a social anthropologist who maintains long-term collaborative projects investigating knowledge and its appropriate presentation with indigenous villagers on the North Coast of Papua New Guinea. He is a Directeur de recherche with the CNRS, based in the Centre for Research and Documentation of Oceania at Aix-Marseille University, and a Professor of Anthropology at the University of Western Australia.

James Leach Centre de Recherche et de Documentation sur l'Océanie, (AMU, CNRS, EHESS)/Anthropology and Sociology University of Western Australia Maison Asie Pacifique Aix-Marseille Université

3 place Victor Hugo Marseille 13003

France 